\title{
32. ヒートアイランド現象の緩和による泠房エネルギー消費の抑制に関する解析的研究
}

\section{Numerical analysis of heat island phenomena for the control of cooling energy in cities}

足永靖信*・ヴタン力**・浅枝隆***

Yasunobu ASHIE, Vu Thanh Ca and Takashi ASAEDA

\begin{abstract}
The reduction of urban heat island phenomena is specified in the principle of Japanese government as a countermeasure for the global warming problem. Air temperature of Tokyo has risen as $1.7^{\circ} \mathrm{C}$ in summer since last century. This climatic change may be a match for 34 billion yen as a negative effect on the seasonal electricity charges summed up in the metropolitan area. A coupling model of urban climate and building air conditioning system was developed for different scale problems of mesoscale $(480 \mathrm{~km} * 400 \mathrm{~km})$ and urban district scale $(500 \mathrm{~m} * 500 \mathrm{~m})$. Turbulent model is a $k$ - $\varepsilon$ type equivalent to the Level 2.5 model by a control of the parameters of coefficient for eddy viscosity evaluation $C_{\mu}$ and turbulent Prandtl number $P_{r t}$ defined as the atmospheric stability functions. The model also involves the drag force effect of building walls. Firstly, the Kanto region was analyzed, and numerical results were compared with the measurement data. Secondly, urban district scale in Tokyo was analyzed, and the numerical results showed distributions of soil temperature and air temperature were highly affected by the land utilization and energy utilization.
\end{abstract}

KE'YWURDS: urban heat island, urban canopy, energy for cooling, COP, air conditioner

\section{1 はじめに}

都市の高温化（ヒートアイランド）現象の緩和は政府の地球温暖化対策推進大綱において対策の一つに揭げら れている。夏季の気温が $1^{\circ} \mathrm{C}$ 上昇すると日本全体で電力消費量は $60 \sim 120$ 万 $\mathrm{kW}$ 増加すると言われている ${ }^{1)} こ$ の電力量は我が国全体の電力需要（ピーク時）のおおよそ $1 \%$ 、中型原子炕 1 基分の発電容量に相当する。東京の 夏季気温が $1{ }^{\circ} \mathrm{C}$ 上昇すると電力料金で 200 億円の損失が発生するとも言われている ${ }^{2)}$ 。管区気象台資料によると東 京の夏季気温は過去 100 年間に約 $1.7^{\circ} \mathrm{C}$ 上昇していることから都市気温の上昇によって年間 340 億円もの損失が潜 在的に発生している計算になる。これらの統計資料を用いたマクロな推計に対し、大気の流動現象を物理的に予測 する手法はいくつか存在し、海陸風の影響を伴うヒ一トアイランド現象の予測が行われている ${ }^{3445)}$ 。しかし、それ らのほとんどは人工排熱量を与えた計算であるため、そのままの形ではエネルギ一消費量を予測することはできな い。本研究は、ヒートアイランド現象および建物のエネルギー負荷の熱的構造を数理モデル化し、ヒートアイラン ド現象の緩和による冷房エネルギー消費の抑制に関する検討を行うものである。そのために建物の冷房負荷算定モ デルと都市大気モデルの連成システムを構築し、都市気候の形成と人工排熱の発生を動的な形で関係づけることと した。都市大気モデルは土木建築分野で広く用いられている $\kappa$ - モモデルを基本とするが、IP 理論から導かれるレ ベル 2.5 相当の改善を渦粘性係数、熱拡散係数に施すとともに、建物壁の抗力による乱流エネルギーの增大効果を

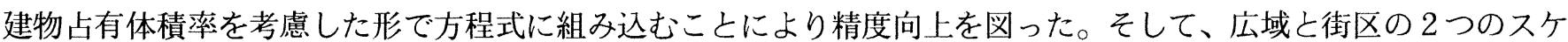
一ルからヒートアイランド現象の予測を試み、都市のエネルギー消費特性について述べたものである。

*建設省建築研究所 Building Research Institute-MOC, Tatehara 1,Tsukuba, Ibaraki, Japan 305-0802

**埼玉大学建設工学科 Department of Civil and Environmental Engineering, Saitama University, Shimo-ohkubo 255,

Urawa, Saitama 338-0825

***埼玉大学大学院理工学研究科 Graduate School of Science and Engineering., Saitama University, Shimo-ohkubo 255, Urawa, Saitama 338-0825 


\section{2 都市大気の乱流モデル}

都市キャノピー層を含む大気境界層を解析においては、現在、土木建築分野で幅広く用いられている $k^{-} \varepsilon モ \vdots$ ルの適用が考えられるが、以下の 2 点に留意して改善を施したものである。

\section{1 ）建物抗力効果の算定}

本来、建物形状の詳細を境界条件に設定し、熱、 湿気の輸送方程式と連成した形で乱流モデルを構築 する必要があるが、広域スケールの解析においては 建物を含む解析ボリュームを想定して抗力効果を N-S 方程式に組み込む方式が考えられる。したがっ て圧力とせん断応力の空間平均化が必要になるが、 流体積分式において圧力 $p$ と有効体積率 $G$ の積、 $G p$ を計算にそのまま用いると、 $G$ 值の小さい都市キャ ノピー層に向かって周囲から風が吹き込む不当な結 果がもたらされる。よって有効体積率の分布により 形成され実質上は抗力に預からない見かけ上のベク トル成分と建物前後の不連続な圧力変化により抗力 として作用する成分の二者を分離した取り扱いが必

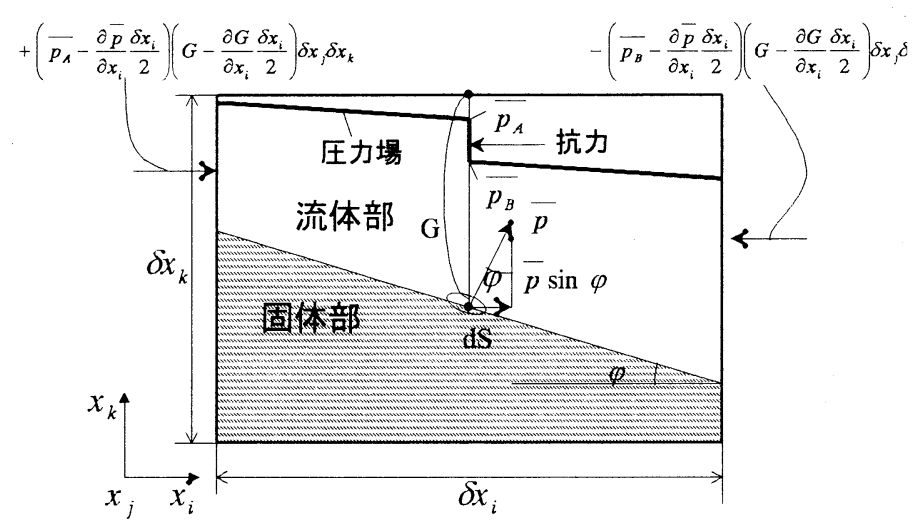

図 1 有効体積率分布を有する流体の圧力バランス 要である。図 1 は $x_{i}$ 方向に有効体積率分布を有する 流体の圧力バランスを示したものである。図中の圧力が不連続になっている箇所に抗力が作用すると考え圧力勾酌 を空間平均化する。

$$
\begin{aligned}
& -\left\langle\frac{\partial p}{\partial x_{i}}\right\rangle=\left\{\left(\overline{p_{A}}-\frac{\partial \bar{p}}{\partial x_{i}} \frac{\delta x_{i}}{2}\right)\left(G-\frac{\partial G}{\partial x_{i}} \frac{\delta x_{i}}{2}\right) \delta x_{j} \delta x_{k} / V_{a}-\left(\overline{p_{B}}+\frac{\partial \bar{p}}{\partial x_{i}} \frac{\delta x_{i}}{2}\right)\left(G+\frac{\partial G}{\partial x_{i}} \frac{\delta x_{i}}{2}\right) \delta x_{j} \delta x_{k} / V_{a}\right. \\
& \left.+\frac{1}{V_{a}} \int \bar{p} n_{i} d S\right\}\left.\right|_{\left(\delta x_{i}, \delta x_{j}, \delta x_{k} \rightarrow 0\right)}=-\frac{\partial\langle\bar{p}\rangle}{\partial x_{i}}-\left(\overline{p_{B}}-\overline{p_{A}}\right) / \delta x_{i}
\end{aligned}
$$

ここで、く : 空間平均の記号、一 : アンサンブル平均の記号、 $V_{a}$ : 任意体積 $V_{0}$ 中の空気の体積、G : 有効体積率 $\left(G=\mathrm{V}_{\mathrm{a}} / \mathrm{V}_{0}\right) 、 \mathrm{p}$ : 圧力、 $\mathrm{x}$ : 距離、 $\mathrm{S}$ : 表面。圧力とせん断応力により作用する実質的な抗力については式(2)を 適用する。式(2)の左辺第 1 項は圧力、第 2 項はせん断応力による抗力である。

$\left(\overline{p_{B}}-\overline{p_{A}}\right) / \delta x_{i}+\frac{1}{V_{a}} \int_{S} \overline{\tau_{i k}} n_{k} d S=a C_{f l} \overline{u_{i}}\left(\left\langle\overline{u_{k}}\right\rangle^{2}\right)^{1 / 2}$

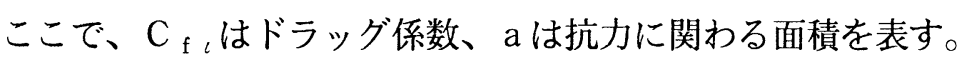

\section{2）大気成層の影響}

大気成層の検討は、Mellor ${ }^{6)}$ 、Yamada ${ }^{7)}$ 、Launder ${ }^{8)} 、\left(\mathrm{Gambo}^{9)}\right.$ により行われているが、本論では $\kappa$ - $モ$ モ゙ルにl ベル 2.5 相当の改善を施す。まず、圧力歪相関項および压力温度変動勾配相関項の rapid termに IP 理論を適用し レイノルズ応力と熱フラックスを次のように表す。

$$
\begin{aligned}
& -\overline{u_{1}^{\prime} u_{3}{ }^{\prime}}=\phi \frac{k \overline{u_{3}{ }^{2}}}{\varepsilon} \frac{\partial\left\langle\overline{u_{i}}\right\rangle}{\partial x_{3}}-\phi \beta \frac{g k \overline{u_{1}^{\prime} \theta}}{\varepsilon} \\
& -\overline{u_{1}^{\prime} \theta^{\prime}}=\phi_{\theta} \frac{k}{\varepsilon}\left(\overline{u_{1}{ }^{\prime} u_{3}}, \frac{\partial\langle\bar{\theta}\rangle}{\partial x_{3}}+\frac{1}{2} \overline{u_{3}{ }^{\prime} \theta}, \frac{\partial\left\langle\overline{u_{1}}\right\rangle}{\partial x_{3}}\right)
\end{aligned}
$$

$$
-\overline{u_{3}{ }^{\prime} \theta}=\phi_{\theta} \frac{k \overline{u_{3}^{2}}}{\varepsilon} \frac{\partial\langle\bar{\theta}\rangle}{\partial x_{3}}+0.8 \phi_{\theta} \beta \frac{g k^{2} \overline{u_{3}^{\prime} \theta^{\prime}}}{\varepsilon^{2}} \frac{\partial\left\langle\overline{\theta_{v}}\right\rangle}{\partial x_{3}}
$$

ここで、 $\phi 、 \phi_{\theta}$ は定数、 $\beta$ は体積膨張係数、gは重力加速度を表す。これらの数式を渦粘性形式に整理すること で、渦動粘性係数と渦熱拡散係数について水平方向と鉛直方向の各值を分離した取り扱いが可能になる。本論は $k$ $\varepsilon$ モデルの浮力効果は鉛直方向の渦粘性モデル係数 $C_{\mu}$ と乱流プラントル数 $P_{r}$ に集約されると考え、これらをフ ックスリチャードソン数 $R_{f}$ の関数として以下に整理した。 
$C_{\mu}=\frac{0.8 \phi \gamma-0.5 \gamma\left(\phi_{\theta}-\gamma\right)}{0.8 \gamma+\phi\left(\phi_{\theta}-\gamma\right)} \frac{0.53-0.94 R_{f}}{1-R_{f}}$

$P_{r t}=P_{r t 0} \frac{1.59-R_{f}\left(1.5 \phi_{\theta}+2.82\right)}{1.59+R_{f}(3 \phi-5.22)} \quad(7), \quad \gamma=\phi_{\theta} \frac{1.59-5.22 R_{f}}{1.59-2.82 R_{f}}$

渦粘性モデル係数 $C_{\mu}$ と乱流プラントル数 $P_{r t}$ についてフラックスリチャードソン数 $R_{f}$ との関係を図 2 に示す。既 往のモデルや実測との対比が良いことから新たに作成した上記の関係式を解析に用いることにする。

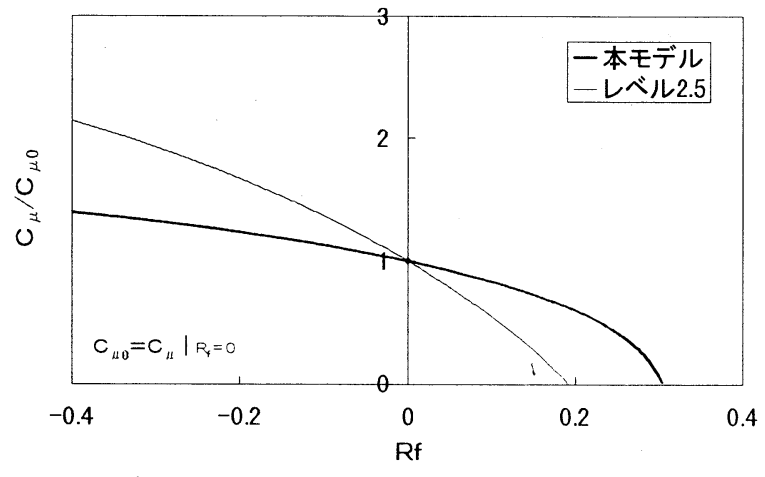

図 $2 \mathrm{a} \quad$ 渦粘性モデル係数 $C_{\mu}$

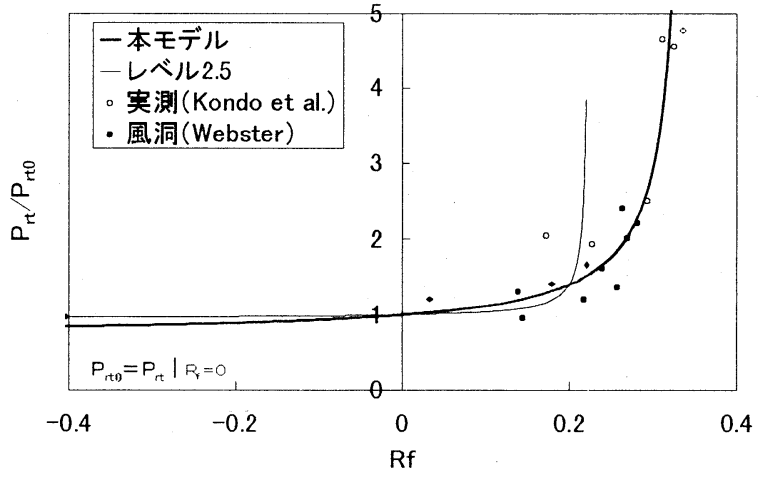

図 $2 \mathrm{~b} \quad$ 乱流プラントル数 $P_{r t}$

都市大気境界層の 3 次元乱流モデルの方程式を図 3 に一覧する。なお、計算エリアの標高に分布が生じるケー スでは地形変換のアルゴリズム ${ }^{10)}$ を適用する。

連続方程式 $\quad \frac{1}{G} \frac{\partial G<\bar{u}_{i}>}{\partial x_{i}}=0$

運動方程式 $\frac{\partial\left\langle\bar{u}_{i}\right\rangle}{\partial t}+\frac{1}{G} \frac{\partial G\left\langle\bar{u}_{i}\right\rangle\left\langle\bar{u}_{k}\right\rangle}{\partial x_{k}}=-\frac{1}{\rho_{a}} \frac{\partial\langle\bar{p}\rangle}{\partial x_{i}}+\frac{1}{G} \frac{\partial}{\partial x_{k}}\left(G v_{t} \frac{\partial\left\langle\bar{u}_{i}\right\rangle}{\partial x_{k}}\right)-\beta g_{i} \delta_{i 3}\left(\left|\bar{\theta}_{v}\right\rangle-\theta_{v 0}\right)-\varepsilon_{i k k} \Omega_{k} \overline{u_{k}}-a C_{f l}\left(\left\langle\bar{u}_{k}\right\rangle^{2}\right)^{0.5} \overline{u_{i}}$

エネルギー輸送方程式 $\quad \frac{\partial\langle\bar{\theta}\rangle}{\partial t}+\frac{1}{G} \frac{\partial G\left\langle\bar{u}_{k}\right\rangle\langle\bar{\theta}\rangle}{\partial x_{k}}=\frac{1}{G} \frac{\partial}{\partial x_{k}}\left(G \frac{v_{t}}{P_{r t}} \frac{\partial\langle\bar{\theta}\rangle}{\partial x_{k}}\right)+\frac{\left\langle\overline{H_{a}}\right\rangle+\left\langle\overline{H_{s}}\right\rangle}{G C_{p} \rho_{a}}$

水蒸気輸送方程式 $\quad \frac{\partial\langle\bar{q}\rangle}{\partial t}+\frac{1}{G} \frac{\partial G\left\langle\bar{u}_{k}\right\rangle\langle\bar{q}\rangle}{\partial x_{k}}=\frac{1}{G} \frac{\partial}{\partial x_{k}}\left(G \frac{v_{t}}{P_{r t}} \frac{\partial\langle\bar{q}\rangle}{\partial x_{k}}\right)+\frac{\left\langle\overline{Q_{a}}\right\rangle+\left\langle\overline{Q_{s}}\right\rangle}{G \rho_{a}}$

乱流エネルギー輸送方程式 $\quad \frac{\partial k}{\partial t}+\frac{1}{G} \frac{\partial G\left\langle\overline{u_{k}}\right\rangle k}{\partial x_{k}}=\frac{1}{G} \frac{\partial}{\partial x_{k}}\left(G \frac{v_{t}}{\sigma_{\kappa}} \frac{\partial k}{\partial x_{k}}\right)+v_{t}\left(\frac{\partial\left\langle\overline{u_{i}}\right\rangle}{\partial x_{k}}+\frac{\partial\left\langle\overline{u_{k}}\right\rangle}{\partial x_{i}}\right) \frac{\partial\left\langle\overline{u_{i}}\right\rangle}{\partial x_{k}}-\varepsilon$

$+g_{i} \beta \frac{v_{t}}{P_{r t}} \frac{\partial\left\langle\overline{\theta_{v}}\right\rangle}{\partial x_{k}} \delta_{i 3}+a C_{f l}\left(\left\langle\overline{u_{k}}\right\rangle^{2}\right)^{3 / 2}$

粘性消散率輸送方程式 $\quad \frac{\partial \varepsilon}{\partial t}+\frac{1}{G} \frac{\partial G\left\langle\overline{u_{k}}\right\rangle \varepsilon}{\partial x_{k}}=\frac{1}{G} \frac{\partial}{\partial x_{k}}\left(G \frac{v_{t}}{\sigma_{\varepsilon}} \frac{\partial \varepsilon}{\partial x_{k}}\right)$

$+\frac{\varepsilon}{\kappa}\left(C_{1 \varepsilon} v_{t}\left(\frac{\partial\left\langle\overline{u_{i}}\right\rangle}{\partial x_{k}}+\frac{\partial\left\langle\overline{u_{k}}\right\rangle}{\partial x_{i}}\right) \frac{\partial\left\langle\overline{u_{i}}\right\rangle}{\partial x_{k}}-C_{2 \varepsilon} \varepsilon+C_{3 \varepsilon} g_{i} \beta \frac{v_{t}}{P_{r t}} \frac{\partial\left\langle\overline{\theta_{v}}\right\rangle}{\partial x_{k}} \delta_{i 3}+C_{p \varepsilon} \frac{k^{3 / 2}}{L_{0}}\right)$

(記号) $\mathrm{t}$ : 時間、 $\mathrm{x}:$ 距離、 $\mathrm{u}$ : 風速、 $\theta$ : 温位、 $\theta_{v}:$ 仮温位、 $\mathrm{q}:$ 混合比、 $\mathrm{p}:$ 圧力、 $\mathrm{k}$ : 乱流エネルギー、 $\varepsilon:$ 粘性消散率、 $\rho_{\mathrm{a}}:$ 空気の 密度、 $\mathrm{H}_{\mathrm{a}}$ : 空気中の熱発生量、 $\mathrm{H}_{\mathrm{s}}$ : 表面の熱発 生量、 $\mathrm{Q}_{\mathrm{a}}$ : 空気中の水蒸気発生量、 $\mathrm{Q}_{\mathrm{s}}$ : 表面の 水蒸気発生量、 $G$ : 有効体積率、 $a$ : 抗力面積、 $\mathrm{P}_{\mathrm{rt}}$ : 乱流プラントル数

(定数) $\Omega_{\mathrm{k}}, \mathrm{C}_{\mathrm{f}}, \mathrm{C}_{1 \varepsilon}, \mathrm{C}_{2 \varepsilon}, \mathrm{C}_{3 \varepsilon}, \mathrm{C}_{\mathrm{p} \varepsilon}$

図 3 都市大気境界層の 3 次元乱流モデルの方程式 


\section{3 建物空調モテル}

建物空調モデルの算定手順を図 4 に示す。建物各面（東 四南北の壁面および屋上面）の対流放熱量および人工排熱 量について顕熱、潜熱の発生量を算定し、大気乱流モデル と連成解析を行う。室内熱負荷は壁の層構成を考慮して熱 伝導方程式を解き、壁、開口部の貫流熱、開口部からの日 射侵入および内部発熱、換気交換熱を合算して求めている。 熱輸送方程式のソース項は大気放射による熱取得、建物表 面から大気への顕熱量、空調システムからの排熱量から構 成され、該当するメッシュに与えられる。建物キャノピー の放射解析は、建物の日陰、壁地表間の形態係数および多 重反射を考慮している。図 5 に算定対象にした面々形態係 数 ${ }^{11)}$ 示す。空調システムの熱源機器は部分負荷率、気温

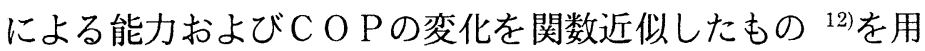
いている（図 6 )。

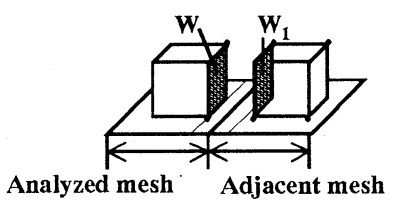

a) $W$ and $W 1$

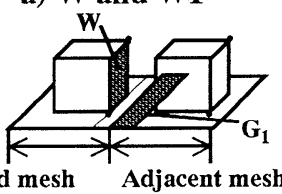

b) $W$ and $G_{1}$

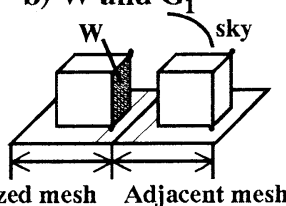

c) W and sky

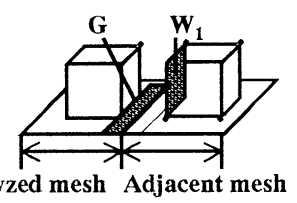

d) $\mathrm{G}$ and $\mathrm{W} 1$

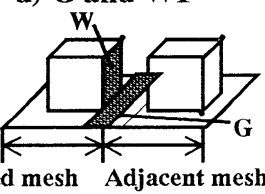

e) $G$ and $W$

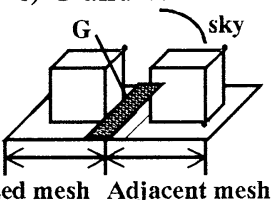

f) $G$ and sky
図 5 算定対象にした面々形態係数

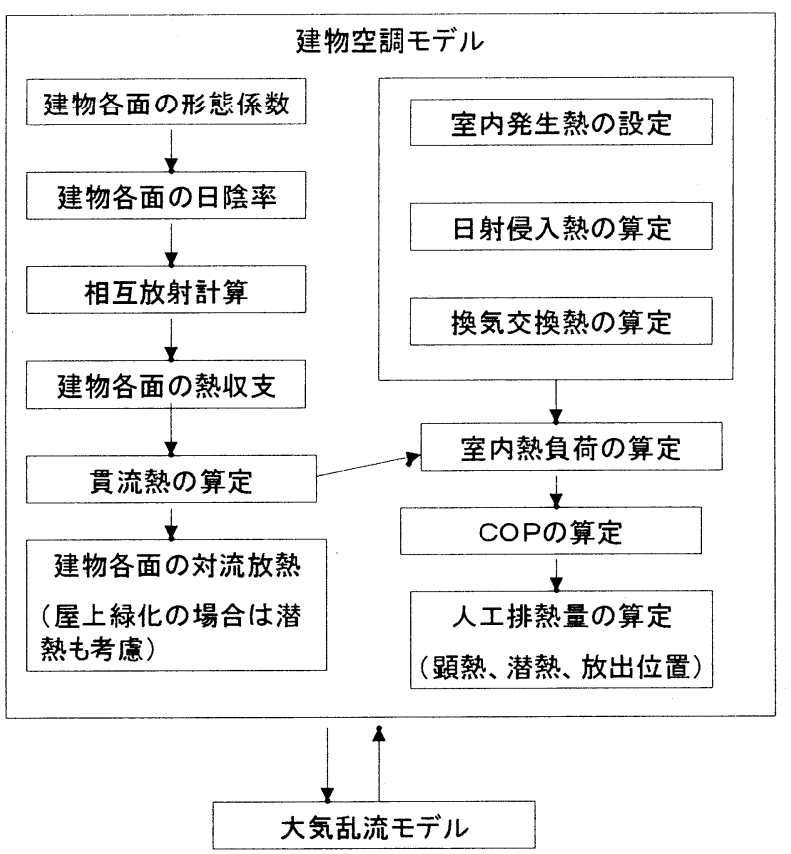

図 4 建物空調モデル

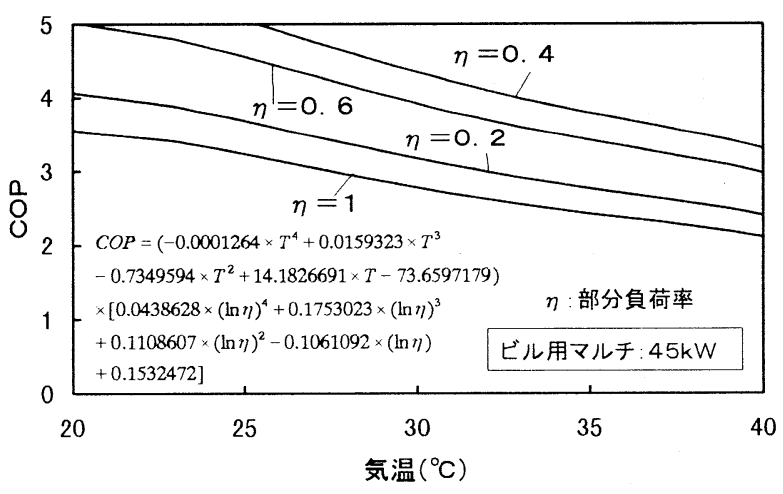

図 6 熱源機器の C O P 特性

\section{4 広域スケールの解析}

関東地域を含む広域（480km*400km）の解析例を述べる。国土地理院のD E M (250m 標高メッシュ)、国土庁 の国土数值情報（100m メッシュ）を用いて $8 \mathrm{~km}$ メッシュの入力デー夕を作成した。国土数值情報の建物建物用 地については、建物空調モデルを適用したが、容積率等の詳細な情報が含まれていないため、東京都資料から平均 的な建物関連デー夕を割り出し、建坪率 $50 \%$ 、階数 3 階、R C 建物（熱 物性用）を設定した。実際には建物の用途等が地域で異なるため、今後 はより詳細な建物データを用いた検討が必要である。図 7 は気温の計算 結果を示したものである。首都圈を中心として高温域が形成されており、 沿岸に近い東京都に比へ内陸側の埼玉県の近辺が暑くなっている。千葉 県の房総半島では海風の恩恵により気温が低めに表れている。図 8 は昼 間の風分布を示したものである。海風の発達が見られアメダスデータ（図 9 ）と良く一致している。特に鹿島灘からの南東風之相模湾の南方風が 関東平野に入って埼玉県の西方で収束する傾向が再現されている。図 10 は人工排熱の分布を示したものである。人工排熱は冷房のエネルギー消

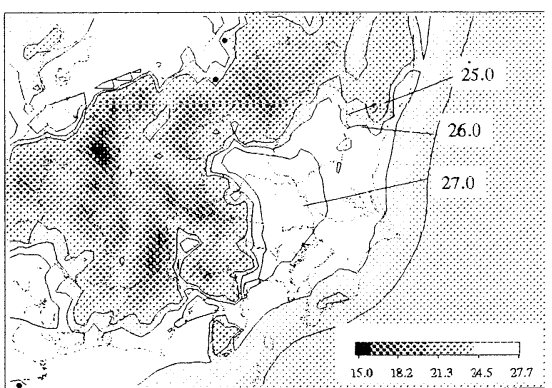

図 7 夏季の気温分布 (15 時の解析結果) 
費量と冷房負荷の和を土地面積あたり（この場合 $8 \mathrm{~km} * 8 \mathrm{~km}$ ) で表したものである。首都圈を中心にピークで約 100 〜 150W/m²の值になっており、エネルギー消費が集中していることが分かる。

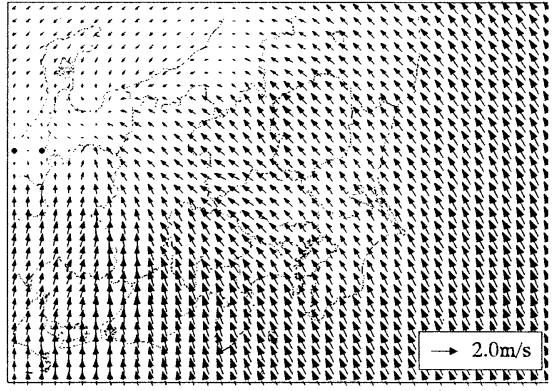

図 8 夏季の風速分布

(15 時の解析結果)

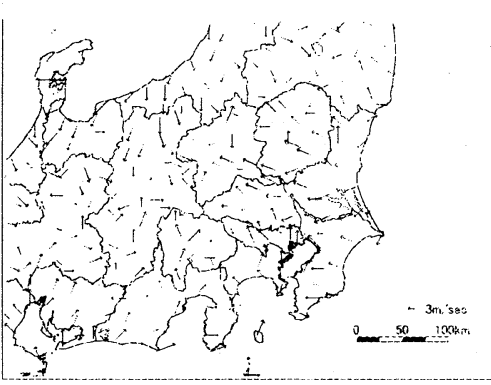

図 9 アメダスによる風速分布 （1997 年 8 月 21 日 15 時）

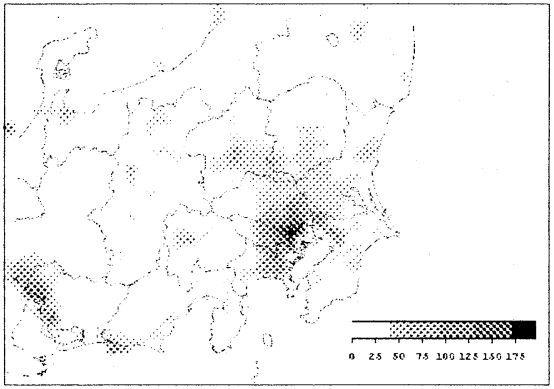

図 10 建物の人工排熱分布 (15 時の解析結果 $\mathrm{W} / \mathrm{m}^{2}$ )

\section{5 詳細スケール（街区）の解析}

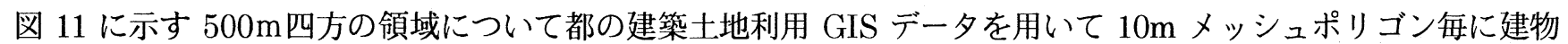
の用途、階数、構造、緑地、道路等の占有割合を求め解析プログラムに入力した。住宅系は家庭用エアコン、業務 系の場合ビル用マルチの空調システムを想定し、各々の COP 関数を用いた。日中の対流混合を考慮して上空 $1500 \mathrm{~m}$ までを解析領域としたが、地域風の影響を取り入れるため ナッジングを行い $100 \mathrm{~m} \sim 800 \mathrm{~m}$ 高さに風向風速の日変動 值を設定した。図 12 に気温の分布を示す。緑地の周辺で はクールスポットが形成されており、0.5 $1.0^{\circ} \mathrm{C}$ 前後低い。

図 13 の地表面温度分布は土地被覆の影響が顕著に見受け られ、道路部分の高温化が明瞭に現れている一方、樹林部 分は低温域になっている。その差は $20^{\circ} \mathrm{C}$ 以上に達している。

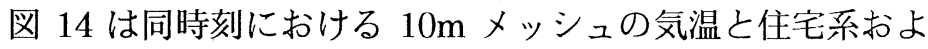
び業務系の COP の関係を示している。両者ともに気温が 上昇すると COP の值が低下する傾向が見られ、 $1^{\circ} \mathrm{C}$ 当たり

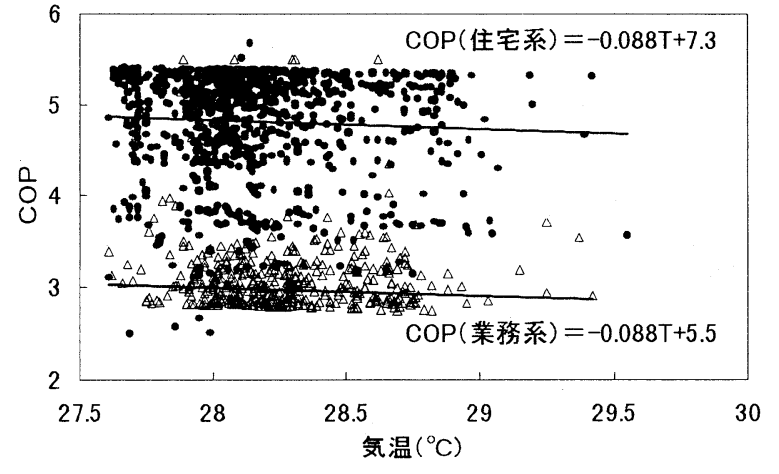

図 14 気温と C O Pの関係 の低下割合はともに約 $9 \%$ である。

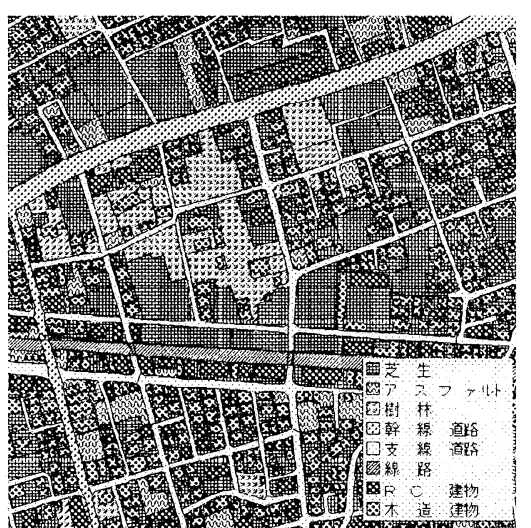

図 11 解析対象地区の土地利 用分布 (東京都建築土地利用 GIS データによる)

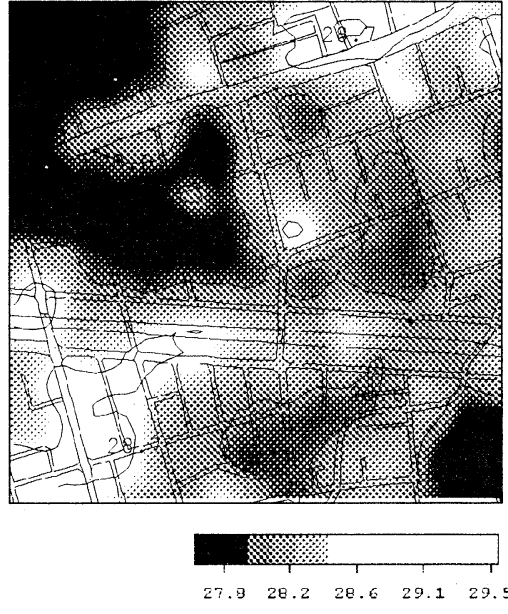

図12 気温分布の解析結果 （夏季 15 時）

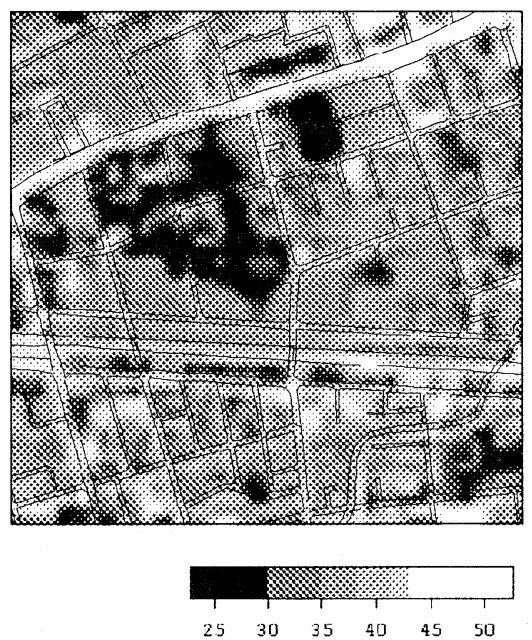

図 13 表面温度分布の解析結果

（夏季 15 時） 


\section{6 緑地の省エネルギー効果に関する検討}

前掲地区は樹木、草地等の割合が比較的多いが（樹林率 9\%、草地率 $39 \%$ )、今後の開発により例えば駐車場の建 設によりアスファルト化する場合が予想される。そこで、 地区の緑が全てアスファルト化された場合の計算を行い、 気温やエネルギー負荷への影響を調べることにする。開発 後の熱環境を現状の計算結果と比較したのが図 15 である。 図中の夜間気温は 5 時の地区平均値、日中気温は 15 時の 地区平均值、地区エネルギーは地区冷房エネルギー消費量 の日総量值を表すものである。地区開発により、日中、夜 間の気温が $0.5 \sim 0.6^{\circ} \mathrm{C}$ 上昇し、日中の活動時や就寝時の体 感温度に少なからぬ影響が予想される。冷房エネルギー消 費量は約 $8 \%$ 増加する。これは 1 世帯の電力料金にすると 1 シーズン $500 \sim 1000$ 円に相当する。

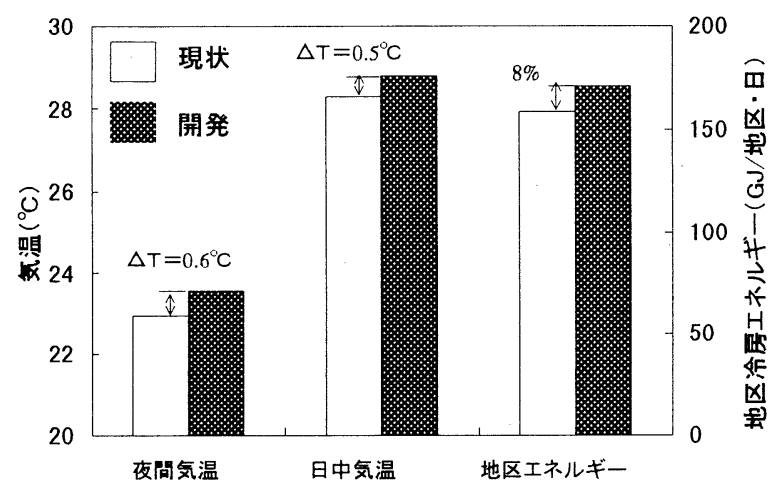

図 15 数值計算による地区開発の熱環境影響予測

\section{7 おわりに}

広域と街区の $2 つ$ のケールから都市の熱環境予測を試みた。その結果、緑地率 5 割の当該地区は潜在的に約 $8 \%$ の省エネルギー効果を地域の緑から享受していることが示された。この解析手法は様々なスケールの都市開発に適 用可能であり、ヒートアイランド緩和施策の定量的検討に活用したいと考えている。

\section{参考文献}

1 ）環境負荷の小さな都市環境整備の支援体制整備のあり方についての検討、建設省都市局、1999.3

2 ）建設省都市局資料

3) 村上周三、持田灯他 : 関東地方における土地利用状況の変化と流れ場・温度場の解析（Mellor-Yamada 型の 都市気候モデルによる局地気候解析)、日本建築学会計画系論文集、第 491 号、pp.31-39、1997.1

4 ) Kimura, F. and S. Arakawa: A numerical experiment in the nocturnal low level jet over the Kanto plain, J. Meteorol. Soc. Japan, 61-6, pp.848-861, 1983

5 ) Ichinose, T. et al.: Impact of anthropogenic heat on urban climate in Tokyo, Atmospheric Environment 33, pp.3897-3909, 1999

6 ) Mellor, G. L.: Analytic prediction of the properties of stratified planetary surface layers, J. Atmos. Sci., 30 , pp.1061-1069, 1973

7 ) Yamada, T: The critical Richardson number and the ratio of the eddy transport coefficients obtained from a turbulence closure model, J. Atmos. Sci., 32, pp.926-933, 1975

8 ) Launder, B. E.: On the effects of a gravitational field on the turbulent transport of heat and momentum, J. Fluid Mech., 67, part 3, pp.569-581, 1975

9 ) Gambo, K.: Notes on the turbulence closure model for atmospheric boundary layer, J. Meteor. Soc. Japan, 56-5, pp.466-480, 1978

10) Yamada, T. and S. Bunker: Development of a nested grid, second-moment turbulence closure model and application to the 1982 ASCOT brush creek simulation, J. Appl. Meteorol., 27, pp.562-578, 1988

11）渡辺要：建築計画原論 II、p.13、丸善、1965

12）足永靖信、田中稔、山本亨 : 事務所建物の空調システムの排熱特性に関する研究、空気調和・衛生工学会論 文集、No.75、pp.89-97、1999.10 